\title{
FROTHER CRITICAL COALESCENCE CONCENTRATION AND DOSE IN FLOTATION OF COPPER-BEARING CARBONACEOUS SHALE
}

\author{
Danuta SZYSZKA* \\ Faculty of Geoengineering, Mining and Geology, Wrocław University of Science and Technology, Wybrzeze \\ Wyspianskiego 27, 50-370 Wrocław
}

\begin{abstract}
The paper presents the yield of carbon-and-cooper-bearing shale from the Legnica and Glogow Copper Basin flotation also called Kupferschiefer in the presence of ethylene, diethylene and trithylene glycol butyl ethers $\left(\mathrm{C}_{4} \mathrm{E}_{1}, \mathrm{C}_{4} \mathrm{E}_{2}, \mathrm{C}_{4} \mathrm{E}_{3}\right)$ frothers characterized by frother normalized concentration that is ratio of the frother concentration, and its critical coalescence concentration expressed in different units. It was found that the oucome of flotation is identical provided that the frother concentration is expressed in milimoles per $\mathrm{Mg}$.
\end{abstract}

Keywords: frothers, floatation, copper-bearing shale, Critical Coalescence Concentration (CCC)

\section{INTRODUCTION}

Shale is an important component of sedimentary ores with increased content of carbon and metals, especially copper. The copper-bearing shale present in the ore originated from the Legnica and Glogow Copper Basin in Poland in literature known as Kupferschiefer (Kijewski and Leszczyński 2010; Pactwa 2012) causes difficulties during upgrading by flotation. Therefore, it should be processed separately, possibly by the so-called pre-flotation with only frothers (Szyszka et al. 2014a). According to flotation tests, called flotometry, this copper-bearing carbonaceous shale is apparently hydrophilic, since it does not float in distilled water in a Hallimonda cell

\footnotetext{
* Corresponding author: danuta.szyszka@pwr.edu.pl (D. Szyszka)
} 
(Drzymała and Bigosiński 1995). However, numerous studies have demonstrated that this shale is floatable when treated with frothers (Szyszka et al. 2014a; Szyszka et al. 2014b; Szyszka et al. 2015; Kowalczuk et al. 2014; Witecki et al. 2014). The flotation of Kupferschifer shale is very efficient in the vicinity of the so-called Critical Coalescence Concentration (CCC) (Szyszka et al., 2014b).The CCC is a minimum concentration of a frother, at which coalescence of air bubbles in flotation cell during floatation process is efficiently prevented. $C C C$ depends on many parameters. For instance, the larger the molecular weight of a frother, the lower the $C C C$ value (Szyszka et al., 2008). Szyszka (2018) and Kowalczuk (2013) demonstrated existence of a significant correlation between $C C C$, molecular weight and hydrophillic-lipophilic balance (HLB).

There are other indicators of frother ability to form foam or froth such as DFI (Dynamic Foaming Index) (Malysa et al., 1978; Czarnecki et al., 1982), rate of water transfer to foam at $25 \%$ concentration of air in foam $J_{w, g g}=25 \%$ (Moyo et al. 2007) and maximum mechanical uplift of fine grains to foam $\varepsilon_{\max }$ (Szyszka 2007). Initial investigation of these indices suggests that, except of DFI, they are similar each other (Szyszka et al. 2008). It is to point out that according to Drzymala (2016, data not published) the DFI-index becomes similar to other indices of frother activity when used in form of 1/DFI. The aim of this paper is to find the relationship between shale flotation yield and $C C C$ as well as dose of the frothers.

\section{METHODOLOGY}

The Critical Coalescence Concentration of ethylene, diethylene and trithylene glycol butyl ethers $\left(\mathrm{C}_{4} \mathrm{E}_{1}, \mathrm{C}_{4} \mathrm{E}_{2}, \mathrm{C}_{4} \mathrm{E}_{3}\right)$ frothers was investigated earlier by this author (Szyszka 2018). It was measured in a $89 \mathrm{~cm}^{3}$ high flotation cell. Air was pumped to the cell using a peristaltic pump through two thin capillaries firmly fixed to a metal plate. Air flow rate was of $5 \mathrm{dm}^{3} / \mathrm{min}$. The measurements were made once the system being analysed has reached the equilibrium state. The process of air bubble formation was recorded using a NICON D5000 digital camera of a 12.5 megapixel matrix with NIKKOR AF-S lens and resolution of $2144 \times 1424$ (JPEG). The images of the best quality were selected and used to analyse and measure average Sauter mean (Pacek et al. 1998) diameters of air bubbles in the given concentration of the frother. The parameters used to determine the $C C C$ and flotation tests for these compounds are summarized in Table 1. The ethers used as frothers, e.g.: ethylene glycol butyl ether $\left(\mathrm{C}_{4} \mathrm{E}_{1}\right)$ and diethylene glycol butyl ether $\left(\mathrm{C}_{4} \mathrm{E}_{2}\right)$, as well as triethylene glycol butyl ether $\left(\mathrm{C}_{4} \mathrm{E}_{3}\right)$ were chemically pure. All three ethers are present in the industrial reagent known as Nasfroth (KGHM 2013) frother. Characteristics of the frothers are also presented in Table 1. The CCC of tested chemicals expressed in different units are given in Table 2. 
Table 1. Characteristics of frothers used in the study

\begin{tabular}{|c|c|c|c|c|c|c|c|}
\hline Item & $\begin{array}{c}\text { Family } \\
\text { of compounds }\end{array}$ & \multicolumn{3}{|c|}{ Name } & $\begin{array}{l}\text { Molecular } \\
\text { formula }\end{array}$ & $\begin{array}{c}\mathrm{MW} \\
\mathrm{Mg} / \mathrm{mol}\end{array}$ & $\begin{array}{c}C C C \\
\mathrm{mmol} / \mathrm{dm}^{3}\end{array}$ \\
\hline 1 & \multirow{3}{*}{$\begin{array}{l}\text { Alkyl ethers } \\
\text { of ethylene } \\
\text { glycol }\end{array}$} & \multirow{3}{*}{ 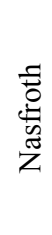 } & $\begin{array}{l}\text { Ethylene glycol } \\
\text { butyl ether }\end{array}$ & $\mathrm{C}_{4} \mathrm{E}_{1}$ & $\mathrm{C}_{6} \mathrm{H}_{14} \mathrm{O}_{2}$ & 118.1 & 1.190 \\
\hline 2 & & & $\begin{array}{l}\text { Diethylene glycol } \\
\text { butyl ether }\end{array}$ & $\mathrm{C}_{4} \mathrm{E}_{2}$ & $\mathrm{C}_{8} \mathrm{H}_{18} \mathrm{O}_{3}$ & 162.2 & 0.84 \\
\hline 3 & & & $\begin{array}{l}\text { Triethylene glycol } \\
\text { butyl ether }\end{array}$ & $\mathrm{C}_{4} \mathrm{E}_{3}$ & $\mathrm{C}_{10} \mathrm{H}_{22} \mathrm{O}_{4}$ & 206.2 & 0.540 \\
\hline
\end{tabular}

Table 2. Different methods of expressing concentrations used in flotation

\begin{tabular}{|c|c|c|c|c|c|}
\hline Frother & $\begin{array}{l}\text { Consumption } \\
\text { g/Mg }\end{array}$ & $\begin{array}{l}\text { Concentration } \\
\mathrm{mmol} / \mathrm{dm}^{3}\end{array}$ & $\begin{array}{l}\text { Yield } \\
\%\end{array}$ & $\begin{array}{c}C C C \\
\mathrm{mmol} / \mathrm{dm}^{3}\end{array}$ & $\mathrm{C} / \mathrm{CCC}$ \\
\hline \multirow{3}{*}{$\mathrm{C}_{4} \mathrm{E}_{1}$} & 300 & 0.0288 & 88.2 & \multirow{3}{*}{1.190} & 0.152 \\
\hline & 100 & 0.0048 & 69.6 & & 0.025 \\
\hline & 75 & 0.0012 & 33.2 & & 0.006 \\
\hline \multirow{3}{*}{$\mathrm{C}_{4} \mathrm{E}_{2}$} & 250 & 0.0294 & 92.6 & \multirow{3}{*}{0.840} & 0.035 \\
\hline & 150 & 0.0147 & 87.0 & & 0.017 \\
\hline & 50 & 0.0059 & 53.7 & & 0.007 \\
\hline \multirow{4}{*}{$\mathrm{C}_{4} \mathrm{E}_{3}$} & 243 & 0.0256 & 91.3 & \multirow{4}{*}{0.540} & 0.047 \\
\hline & 144 & 0.0128 & 86.6 & & 0.024 \\
\hline & 111 & 0.0085 & 84.6 & & 0.016 \\
\hline & 78 & 0.0043 & 48.0 & & 0.008 \\
\hline
\end{tabular}

The air bubble coalescence in the tested solutions of frothers was investigated in a flotation cell. The air bubble diameters determined for the tested concentrations of frothers were re-calculated into the Sauter mean diameters, and subsequently, the graphs were plotted, which were later used to determine the $C C C$ values using an approximation method. Copper-bearing shale from ZG Rudna site was used for flotation tests (KGHM Polska Miedź S.A. company). The sample for flotation testing was ground in a cone crusher twice, and subsequently, in a jaw crusher; and finally, passed through a finger disintegrator. The particle size of the shale selected for flotation was smaller than $100 \mu \mathrm{m}$.

Flotation was performed using a mechanical laboratory flotation machine fitted with a $0.25 \mathrm{dm}^{3}$ cell. All flotations were carried out using the same impeller speed $(670 \mathrm{rpm})$ and air flow rate $\left(80 \mathrm{dm}^{3} / \mathrm{h}\right)$. After five minutes of agitation, a specific $\mathrm{g} / \mathrm{Mg}$ amount of an appropriate frother was added, and the machine continued to run for one minute.

After that time, the air-supply valve of the flotation machine chamber was opened. Froth that appeared on the surface was removed manually and used determine the yield of flotation. Tap water was used in all flotation tests. The flotation products were dried in a laboratory drier at $100{ }^{\circ} \mathrm{C}$. Once dried, the material was weighed, and yield of each product was calculated. 


\section{RESULTS AND DISCUSSION}

Flotation tests of the copper-bearing shales using ethylene glycol butyl ether $\left(\mathrm{C}_{4} \mathrm{E}_{1}\right)$ and diethylene glycol butyl ether $\left(\mathrm{C}_{4} \mathrm{E}_{2}\right)$, as well as triethylene glycol butyl ether $\left(\mathrm{C}_{4} \mathrm{E}_{3}\right)$ were carried out to determine how concentration of frothers influences the flotation yield. The results are given in Fig. 1. The conentration of frother is given in: a) in grams of frother per megagrams of feed material $(\mathrm{g} / \mathrm{Mg})$, (b) in millimol of frother per $\mathrm{dm}^{3}$ of solution. Figure 1 shows that each frother to a diffrent extend influences the flotation results.

(a)

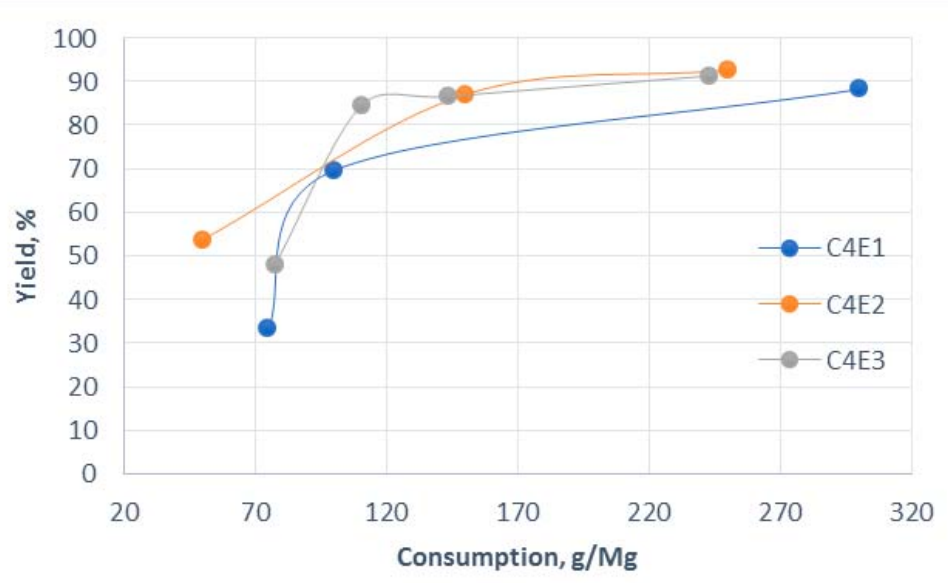

(b)

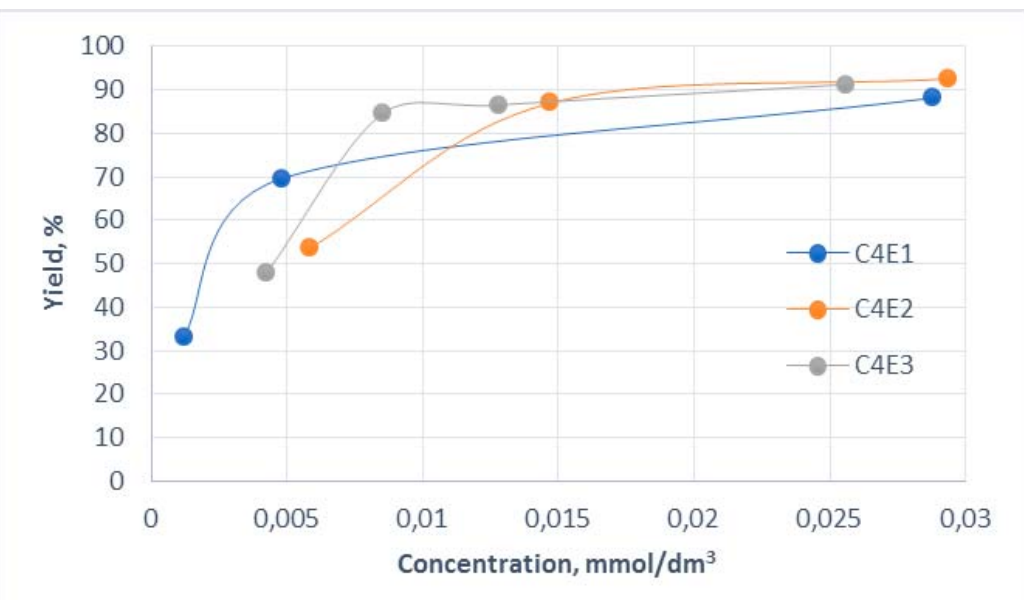

Fig. 1. Shale yield depending on frother dose expressed (a) in grams of frother per megagrams of feed material $(\mathrm{g} / \mathrm{Mg})$, (b) in millimol of frother per $\mathrm{dm}^{3}$ of solution 


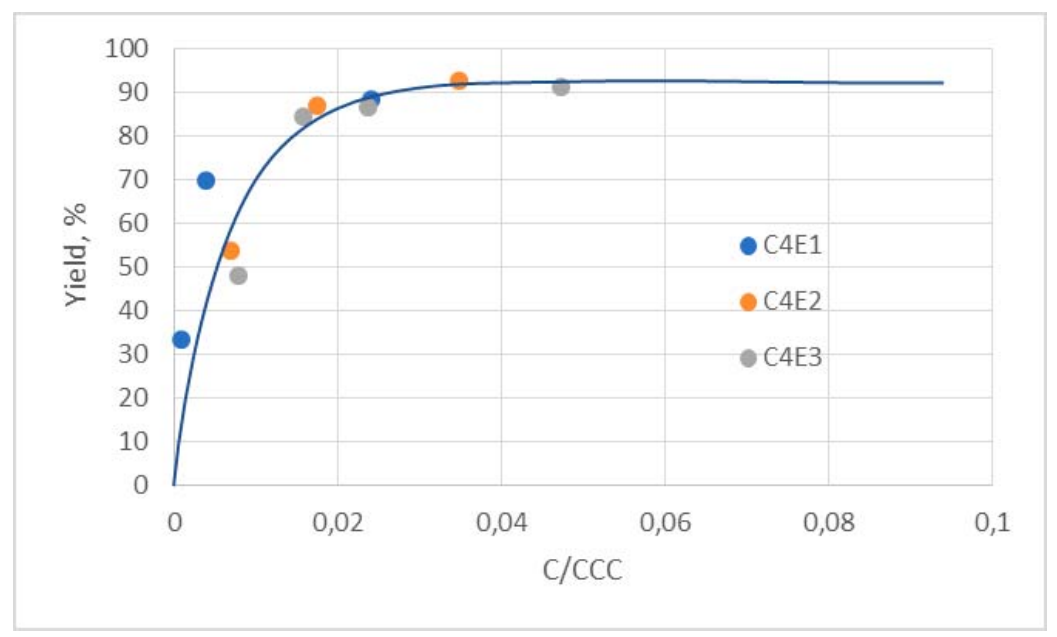

Fig. 2. Shale yield depending on frother dose expressed as normalized concentration $(C / C C C)$

The aim of this paper was to compare flotation yield of shale in the presence of three frothers from the same family of etylene butyl ethers. Values obtained were also presented graphically, as correlation between the shale yield and frother concentration. The latter may be presented in various ways, including grams of frother per megagrams of feed material, millimol of frother per volume of solution in which flotation is being conducted, or else as normalized $C / C C C$ concentration; three figures are presented in the paper (Figs. 1a, 1b, and 2). In the expression, $C / C C C$ stands for frother concentration, whereas $C C C$ stands for Critical Coalescence Concentration, i.e., concentration of a frother that does not cause gas bubbles to coalesce. In the case of use of normalized $C / C C C$ concentration, frother concentration units must be the same. Table 2 presents frother concentrations used in the study expressed in three abovementioned ways.

\section{SUMMARY AND CONCLUSIONS}

This paper presents the values of Critical Coalescence Concentration $(C C C)$ determined here experimentally and adopted from literature for selected chemical compounds, which were investigated in numerous studies.

Figures included in the study show that presentation of correlation of shale yield and normalized $C / C C C$ concentration provides information on the studied frothers. A comparison of Figs. 1 and 2 shows that the effect of those frothers is similar, but different amounts of those frothers are required, resulting from the capability of those frothers to prevent gas bubble coalescence, characterized by $C C C$. 
The presented Critical Coalescence Concentration values extend the data base describing various chemical compounds as candidates for frothers in flotation of ores, especially the copper-bearing ores containing shale.

\section{ACKNOWLEDGMENTS}

This study has been carried out to some extent within the framework of the statutory job of the Wrocław University of Technology No. S 50167.

\section{REFERENCES}

CHO Y.S., LASKOWSKI J.S., 2002a, Effect of flotation frothers on bubble size and foam stability, Int. J. Miner. Process., 2002, 64, 69-80.

CHO Y.S., LASKOWSKI J.S., 2002b, Bubble coalescence and its effect on bubble size and foam stability, Canadian J. Chem. Eng., Vol. 80, 299-305.

CZARNECKI J., MAŁYSA K., POMIANOWSKI A., 1982, Dynamic Frothability Index, J. Coll. Interface Sci., Vol. 86, 570-572.

DRZYMALA J., BIGOSINSKI J., 1995, Collectorless flotation of sulfides occurring in the Fore-Sudetic copper minerals deposit of SW Poland, Mineralogia Polonica, 26 (1), 63-73.

FINCH J.A., NESSET J., ACUNA C., 2008, Role of frother on bubble production and behaviour in flotation, Miner. Eng., 21, 949-957.

GRAU R., LASKOWSKI J.S., HEISKANEN K., 2005, Effect of Frothers on Bubble Size, Int. J. Miner. Process., 225-233.

GUPTA A.K., BANERJEE P.K., MISHRA A., SATISH P., PRADIP, 2007, Effect of alcohol and polyglycol ether frothers on foam stability, bubble size and coal flotation, Int. J. Miner. Process., 82, 126-137.

KOWALCZUK P.B., 2013, Determination of critical coalescence concentration and bubble size for surfactants used as flotation frothers, Ind. Eng. Chem. Res., 52 (33), 11752-11757.

KOWALCZUK P.B., BULUC B., SAHBAZ O., DRZYMALA J., 2014, In search of an efficient frother for pre-flotation of carbonaceous shale from the Kupferschiefer stratiform copper ore, Physicochem. Probl. Miner. Process., 50 (2), 835-840.

LASKOWSKI J.S., 2004, Testing flotation frothers. Physicochemical Problems of Mineral Processing, $38,13-22$.

LASKOWSKI J.S., TLHONE T., WILIAMS P., DING K., 2003, Fundamental properties of the polyoxypropylene alkyl eter flotation frothers, Int. J. Miner. Process., 72, 289-299.

MALYSA K., CZUBAK-PAWLIKOWSKA J., POMIANOWSKI A., 1978, Frothing Properties of Solutions and Their Influence on the Floatability. Proc. 7th Int. Congress Surface Actives Substances, Moscow, Vol. 3, 513-520.

MOYO P., GOMEZ C.O., FINCH J.A., 2007, Characterizing frothers using water carrying rate, Canadian Metallurgical Quarterly, Vol. 46, No. 3, 215-220.

PACEK A.W., MAN C.C., NIENOW A.W., 1998, On the Sauter mean diameter and size distributions in turbulent liquid/liquid dispersions in a stirred vessel, Chemical Engineering Science, 53, 11, 2005-2011.

SZYSZKA D., DRZYMAŁA J., ŁUCZYŃSKI J., WILK K.A., PATKOWSKI J., 2006, Concentration of $\alpha$-terpineol and (2-dodecanoyloxyethyl)trimethylammonium bromide required for prevention of air bubble coalescence in aqueous solutions, Physicochemical Problems of Mineral Processing, 40, 53-59.

SZYSZKA D., DRZYMALA J., MIELCZARSKI E., MIELCZARSKI J., 2008, Entrainment of quartz in flotation tests with frothers, [In:] Proceedings of XXIV International Mineral Processing Congress, IMPC 
2008, Beijing, China, 24-28 September 2008, ed. by Wang Dian Duo et al., Science Press, cop. 2008, Beijing, 1068-1073.

SZYSZKA D., 2013, Critical Coalescence Concetration (CCC) as a parameter for evaluation of selected quaternary ammonium compounds, Mining Science, 20.

SZYSZKA D., 2014, Critical Coalescence Concentration (CCC) for surfactants in aquerous solutions. Proceedings of International Mineral Processing Congress, IMPC 2014, October 20-24, Santiago, Chile.

SZYSZKA D., SIWIAK M., KOWALCZUK P.B., 2014a, Kinetyka flotacji tupka miedzionośnego za pomocq eteru butylo-trójpropylenoglikolowego $\left(C_{4} P_{3}\right)$, [w:] Lupek miedzionośny, Wydział Geoinżynierii, Górnictwa i Geologii, Politechnika Wrocławska, Wrocław, 65-69 (Kinetics of flotation of copper-bearing shale using triethylene glycol butyl ether $\left(C_{4} E_{3}\right)$, [In:] Copper-Bearing Shale, Faculty of Geoengineering, Mining, and Geology, Wroclaw University of Technology, Wroclaw, 65-69).

SZYSZKA D., PĄZIK P., ZWIERZCHOWSKA A., 2014b, Flotacja tupka miedzionośnego w obecności eterów butylowo-etylenoglikolowego i butylowo-dwuetylenoglikolowego, [w:] Lupek miedzionośny, Wydział Geoinżynierii, Górnictwa i Geologii, Politechnika Wrocławska, Wrocław, 103-106 (Flotation of copper-bearing share in the presence of ethylene glycol butyl ether and diethylene glycol butyl ether, [In:] Copper-Bearing Shale, Faculty of Geoengineering, Mining, and Geology, Wrocław University of Technology, Wroclaw, 103-106).

SZYSZKA D., 2018, Critical Coalescence Concentration (CCC) for surfactants in aqueous solutions, Minerals, Vol. 8 (10), 431.

WITECKI K., KOWALCZUK P.B., 2014, Wielkość flotujacych ziarn tupka miedzionośnego w obecności spieniaczy, [w:] Łupek miedzionośny, J. Drzymała, P.B. Kowalczuk (red.), WGGG PWr, Wrocław, 83-90 (Size of flotating copper shale grains in the presence of frothers, [In:] Copper-Bearing Shale, Faculty of Geoengineering, Mining, and Geology, Wrocław University of Technology, Wroclaw, 83-90).

ZHANG W., NESSET J.E., RAO R., FINCH J.A., 2012, Concentration (CCC)95-hydrophile-lipophile balance (HLB) relationship, Minerals, Vol. 2, 208-227.

ZHANG W., NESSET J.E., RAO R., FINCH J.A., 2013, Characterizing Frothers through Critical Coalescence Concentration (CCC)95-Hydrophile-Lipophile Balance (HLB) Relationship, Minerals, Vol. 2, 208-227. 